\title{
Theologians and Philosophers Using Social Media: Advice, Tips, and Testimonials
}

\section{Thomas Jay Oord, editor. Theologians and Philosophers Using Social Media: Advice, Tips, and Testimonials. San Diego: SacraSage, 2017. 442 pp. \$29.90. ISBN: 9780578193991.}

THEOLOGIANS AND PHILOSOPHERS USING SOCIAL MEDIA Advice, Tips, and Testimomias

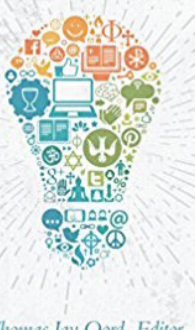

Thomas lay Oond, Editor
I began reading this engaging and slightly overwhelming book for reasons totally unrelated to ATLA: I knew many of the contributors. Despite the title, the book includes scholars from many disciplines in the field of religion - ethics, church history, missions, Bible, and liturgics, just to name a few — and, as a historian myself, I thought I might glean some advice and was curious to see what my friends (and in one case, my spouse) had said.

I was not more than three entries into the book when I saw its applicability to librarianship. Many of us have recently been grappling with the new Ithaka study on the changing practices of religious studies scholars. ${ }^{1}$ This book represents a vast amount of thick ethnographic data bearing out the conclusions of that study: scholars are beginning their research, continuing it, and exchanging its results in a variety of formats, not all of which are under the direct control of librarians. And it is helpfully specific. Which websites, technological tools, and social media formats are scholars using? How are they using them? Who are they talking to?

Every one of the ninety-one entries has slightly different answers to that question, but overall, several things are clear. Scholars are turning to Facebook and Twitter (and to a lesser degree other social media networks) in large numbers to engage ideas, network, disseminate ideas, and share resources. In perhaps the most amazing example, one scholar maintains a Facebook group of over 6,000 people devoted to sharing needed items which he began specifically to take the pressure off his university's ILL. Quite a number of scholars are disseminating open access results of their research not (or not only) via institutional repositories but via their personal blogs, podcasts, and social media accounts (and via Academia. edu, which they are by and large nervous about, but don't see an alternative to). They're worried about how to handle academic rigor and peer review in these new spaces. They're worried about how to communicate with new audiences.

Scholars have always asked each other questions in the hallways without involving librarians, of course. But this book revealed to me the sheer scope of how big those hallways now are, and pointed towards a number of spaces librarians could fruitfully step into, providing guidance through the digital maze. The book has so many contributors that one of them is probably at your school. Find out what their questions are from the book, then set up a time to have coffee or friend them on Facebook, or find them on Twitter, or subscribe to their blog. Talk to them about how you can walk through those spaces together.

Jennifer Woodruff Tait

Editor-in-chief

Theological Librarianship

Richmond, KY

${ }^{1}$ Danielle Cooper et. al., "Supporting the Changing Research Practices of Religious Studies Scholars," February 8, 2017, http://www.sr.ithaka.org/publications/supporting-the-changing-research-practices-of-religious-studies-scholars/. doi. org/10.18665/sr.294119. 